\title{
Handling Covid-19 Related To Regional Security According To Asean Political-Security Community
}

\section{Calvin}

Faculty of Law, Indonesian Catholic University Atma Jaya

Unika Atma Jaya Kampus 3 Bumi Serpong Damai (BSD), Jl. Raya Cisauk Lapan, Sampora, Cisauk, Tangerang City, Banten 15345.

Article Info: $\quad$ Submitted April 9, 2020 Accepted April 26, 2020 Published May 9, 2020

\begin{abstract}
s :
The presence of COVID-19, caused enourmous losses to the society and nation in various aspects of life. One aspect which meant is state security especially in ASEAN. Speaking of the present, no antidote has been completely found to cure COVID-19. This paper is made to find out what effort has been done by South East Asia countries in the aspect of state security, and to find out what effort has been done by ASEAN PoliticalSecurity Community. The author uses juridical-normative research method, which the author did the research based on national and international instruments of law, doctrines, literature and other media. Based on the research results, ASEAN members have issued various policies in purpose to deal with COVID-19 such as: travel ban, social distancing/ physical distancing, and lockdown. Furthermore, all efforts made by ASEAN Political-Security Community are categorized as soft law. Keyword: ASEAN Political-Security Community; COVID-19; Handling Effort; Security; Southeast Asia.
\end{abstract}

\begin{abstract}
Abstrak:
Hadirnya COVID-19 menyebabkan kerugian yang sangat besar dalam berbagai aspek kehidupan berbangsa dan bernegara. Salah satu aspek yang dimaksud adalah aspek keamanan negara, terutama di ASEAN. Hingga kini, belum ditemukan vaksin yang dapat sepenuhnya menyembuhkan COVID19. Sehingga, tujuan dari penulisan ini adalah untuk mengetahui apa saja upaya penanganan yang telah dilakukan oleh negara-negara di kawasan Asia Tenggara dalam aspek keamanan negara, dan untuk mengetahui upaya yang dilakukan menurut ASEAN Political-Security Community. Peneliti menggunakan metode penelitian yuridis-normatif yang meneliti peraturan perundang-undangan, sumber hukum internasional, doktrin, literatur, dan media lainnya. Berdasarkan dari hasil penelitian yang telah dilakukan, anggota ASEAN telah mengeluarkan berbagai kebijakan dalam upaya penanganan COVID-19 seperti: travel ban, social distancing/ physical distancing, dan lockdown. Selain itu, upaya penanganan yang telah dilakukan oleh ASEAN Political-Security Community bersifat soft law. Kata Kunci : ASEAN Political-Security Community; Asia Tenggara; COVID-19; Keamanan; Upaya Penanganan.
\end{abstract}

Citation : Calvin. (2020). Handling COVID-19 Related to Regional Security According to ASEAN Political Security Community. Lex Scientia Law Review 4(1), 19 32. doi : https://doi.org/10.15294/lesrev.v4i1.38195
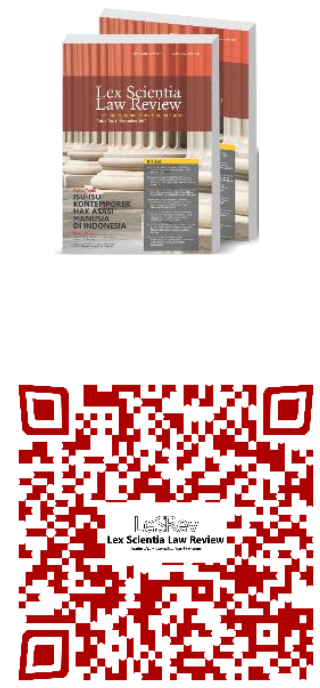

Vol. 4, No. 1

Month May Year 2020

@2020 by Authors. 


\section{Introduction}

In early 2020, a deadly plague has surged the life of society and nation around the world. The plague is known as Coronavirus Disease 2019 (hereinafter COVID-19). COVID-19 is a virus that infects the respiratory system of living creatures. This virus was firstly discovered in the city of Wuhan, People's Republic of China (hereinafter China) at the end of December 2019. Currently, no vaccine effectual to cure COVID-19 completely. This situation was further deteriorated when the WHO (World Health Organization) on March 11, 2020, stated that the Virus outbreak has become a global pandemic. The situation of a global pandemic itself occurs when a disease is easily transmitted from one person to another in many countries at the same time, before the global pandemic situation was declared. Thus, it will encourage countries in the world to consider the security aspects of their respective countries due to the rapid spread of COVID-19. In addition, the statement of the WHO will also make countries to carry out every effort needed to prevent, control the spread and overcome COVID-19. One of the efforts to deal with this problem created by the state itself in the form of issuing various policies. In case of handling efforts, country must consider all aspects of that lives inside the society and the nation itself, in purpose that the handling efforts carried out by one country can also be different from other countries. The other efforts to deal with this are by conducting bilateral or multilateral cooperation, in the scope of regional or universal. The handling effort was carried out with the hope that COVID-19 can be more immediately resolved.

ASEAN Political-Security Community (hereinafter APSC) is one of the three pillars in the ASEAN community (ASEAN Community) formed by ASEAN members. APSC is a pillar that was formed with specialty to establish peace and security in the Southeast Asian region. Peace and security are referred to traditional and / or non-traditional methods. The application of these objectives is not only limited to ASEAN members, but also applies to non-ASEAN members. APSC in carrying out its activities is based on 3 (three) main characteristics as stated in the 2009 ASEAN Political Security Community Blueprint, such as : a rules-based community of shared values and norms; a cohesive, peaceful, stable and resilient region with shared responsibility for comprehesive security; and a dynamic and outward-looking region in an increasingly integrated and interdependent world. ${ }^{1}$ APSC can only carry out its activities if there are several ASEAN members have problems related to state peace and security. This is caused by ASEAN which accommodates APSC represents an intergovernmental organization, which means the position of ASEAN is still below its member countries and will only move if driven by its member countries through making decisions collectively and jointly.

According to data obtained on April 26, 2020, all ASEAN members have been affected by COVID-19. ${ }^{2}$ With all ASEAN countries already affected by COVID-19, there are major problems related to the country's security aspects in the Southeast Asian region. COVID-19 is a non-traditional phenomenon, in which Peter Chalk stated that "broadly, non-traditional phenomena are interpreted as threats to the stability of a country originating from nongovernmental processes carried out by non-state actors". ${ }^{3}$ Laurie Nathan believed that "stability of a country is very necessary in realizing regional cooperation (in APSC), so that threats to state stability will make APSC obliged to take action to restore state stability." 4

\footnotetext{
${ }^{1}$ ASEAN Political Security Blueprint 2009.

2 John Hopkins University. (2020). Coronavirus COVID-19 Global Cases by the Center of Systems Science and Engineering (CSSE). Retrieved from https://www.arcgis.com/apps/opsdashboard/index.html\#/bda7594740fd40299423467b48e9e $\underline{\text { cf6 }}$, Accessed on April 262020.

3 Saragih, H.M. (2017). Kebijakan Pembentukan Komunitas ASEAN 2015: Tantangan dan Harapan dalam Penciptaan Stabilitas Kawasan. Jurnal Administrative Reform. 5 (4). ISSN: 23377542, p. 223.

${ }^{4}$ Jun, Y.C. (2016). Essence of Security Communities: Explaining ASEAN. International Relations of the Asia-Pacific. 16 (3). doi: 10.1093/irap/lcv026, p. 351.
}

\section{https://journal.unnes.ac.id/sju/index.php/IsIr/}


From this background, we can know that it takes a long time to overcome COVID-19. The handling efforts that have been taken by ASEAN members unilaterally can slowly suppress the number of cases of the spread of COVID-19. However, the handling efforts that have been taken by several ASEAN countries are still considered to be less effective and efficient in efforts to prevent, control the spread and overcome this outbreak. Considering all ASEAN members have been affected by COVID-19, the urgency to hold a multilateral cooperation by ASEAN members related to aspects of state security is essential. ASEAN has facilitated the intended cooperation, by utilizing APSC as a pillar that was formed specifically to address issues related to the aspect of state security of ASEAN members. COVID-19 is a non-traditional phenomenon, where ASEAN members during performing unilateral handling efforts will face rigid challenges because they almost never faced problems like those caused by COVID-19. Thus, it is very necessary to carry out cooperation through APSC, which puts forward the principle of shared responsibility to overcome COVID-19.

\section{Research Question}

1. How do ASEAN members respond related to handle efforts on state security after the emergence of COVID-19?

2. What handling efforts that can be done according to the ASEAN PoliticalSecurity Community to overcome COVID-19 in the Southeast Asian region?

\section{Research Methods}

The author uses judicial-normative as a research method in this paper. This type of research is done by analyzing and interpreting theoretical-normative concepts. This type of research requires the writer to study the law deeply. ${ }^{5}$ In this study, researchers conducted research from national and international insruments of law, doctrines, literature, and other media.

\section{Result and Discussion}

\subsection{ASEAN members respond related to handling efforts on state security after the emergence of COVID-19}

Until this research was made and carried out, the spread of COVID-19 is still ongoing. Because the vaccine from COVID-19 has not yet been discovered, COVID19 has caused enormous harm to society and nations in various aspects of life, including economic, state security and social. The Damages is caused by COVID-19 also spread around the world, including the Southeast Asian region. In the Southeast Asian region, all countries have been affected by COVID-19. Various handling efforts have been created by countries that have been affected by COVID19 to improve security for the society and the country to prevent the spread and overcoming COVID-19.

Majority of the countries in the world are based on law (rechtstaat / rule of law), so that means the handling efforts made by these countries are based on the laws that apply in those societies and countries. The purpose of carry out handling efforts based on law is that all countries which are based on law believe that law is a means used to build a better nation and state life. ${ }^{6}$ There are three handling efforts based on the laws that are applied in the country. The intended effort is issuing

\footnotetext{
${ }^{5}$ Fuady, M. (2018). Metode Riset Hukum: Pendekatan Teori dan Konsep. Depok: Rajawali Pers, p. 130-131.

${ }^{6}$ Siallagan, H. (2016). Penerapan Prinsip Negara Hukum di Indonesia. Sosiohumaniora. 18 (2). doi: 10.24198/sosiohumaniora.v18i2.9947, p. 131.
}

https://journal.unnes.ac.id/sju/index.php/IsIr/ 
various policies such as: travel ban, social distance / physical distance, and lockdown.

Travel ban is a policy made by the state in the form of a ban and/ or restriction of citizens who come from certain countries that have been affected by COVID-19. Each country has different policies, so the countries that apply the travel ban policy are based on the subjective assessment of the countries that issued the travel ban policy. The Objective of travel bans by countries that have been affected by COVID-19 is to prevent the spread of COVID-19 and focuses on healing efforts on people who have been affected by COVID-19 in the country.

One of the ASEAN members who implemented travel ban is Indonesia. Indonesia applies a travel ban against foreigners who want to enter the territory of the Republic of Indonesia, which is based on the Minister of Law and Human Rights Regulation (Permenkumham) Number 11 of 2020 concerning on Temporary Prohibitions of Foreigners Entering the Territory of the Republic of Indonesia. Minister of Law and Human Rights Regulation Number 11 of 2020 was issued on March 31, 2020. In Article 2, it was stated that "Prohibiting Foreigners to enter / transit in Indonesian Territory."7

Besides Indonesia, other ASEAN members also apply travel bans in accordance with the laws in those countries. The nature of the travel ban is only temporary during the outbreak. Thus, countries that impose travel ban regulations can revoke travel ban regulations if the subjective assessment of the country considers that the situation is more conducive than before.

The next effort to be taken by ASEAN members is the implementation of social distancing / physical distancing. Social distancing is the act of reducing contact with others, and avoiding activities that involve many people. Physical distancing has a definition similar to social distancing. The WHO in carrying out activities related to COVID-19 more often uses the term physical distancing rather than social distancing, because WHO argued that the use of the term social distancing is incorrect. Dr. Maria Van Kherkove, a WHO epidemiologist states that:

"We're changing to say physical distance and that's on purpose because we want people to still remain connected. So, find ways to do that, find ways through the internet and through different social media to remain connected because your mental health going through this is just as important as your physical health." 8

Handling efforts on issuing social distancing / physical distancing policies carried out by ASEAN members are based on several reasons as follows: COVID-19 is very contagious and spreads rapidly, the incubation period is 2 to 14 days, and there is a great possibility, In which people are located in public places / facilities do not acknowledge that they have been affected by COVID-19. ASEAN members implement social distancing/ physical distancing by issuing a Work from Home policy (hereinafter WFH). WFH is a policy where activities such as the teaching and learning process that were originally at school and / or college, and the process of working initially at the office, company, department store and so on are carried out

\footnotetext{
7 The Ministerial Regulation of Law and Human and Right Number 11 of 2020.

8 World Health Organization. 2020. Physical Distancing. Retrieved from https://www.who.int/docs/default-source/coronaviruse/transcripts/who-audioemergencies-coronavirus-press-conference-full-20mar2020.pdf?sfvrsn=1eafbff_0, Accessed on April 262020.
} 
at home, where these activities continue to run as usual but are carried out with online based method.

For example, Indonesia on March 31, 2020 issued Government Regulation (Peraturan Pemerintah) Number 21 of 2020 concerning on Large-Scale Social Restrictions in the Context of Accelerating the Handling of Coronavirus 2019 (COVID-19). The definition of large-scale social restrictions is contained in Article 1, which states, "large-scale social restrictions are restrictions on certain activities of residents in an area suspected of being infected with Coronavirus Disease 2019 (COVID-19) in such a way as to prevent the possibility of spreading Coronavirus Disease 2019 (COVID-I9)". 9

Then, restrictions on activities as referred to in Article 1, regulated further in Article 4 Government Regulation Number 21 of 2020, which regulates that:

- Article 4 paragraph (1): "Large-scale social restrictions include at least: (a). Leave all school and workplace activities; (b). Restrictions on religious activities; and/ or (c). Restrictions on activities in public places or facilities."10

- Article 4 paragraph (2) Government Regulation Number 21 of 2020: "The limitation of activities as referred to in paragraph (1) letters (a) and (b) must still consider the educational needs, work productivity, and worship of the population."11

- Article 4 Paragraph (3): "The limitation of activities as referred to in paragraph (1) letter (c) is carried out by taking into account the fulfillment of the basic needs of the population. ${ }^{12}$

The provision contained in Article 4 paragraph (1) the government strongly urges the public to implement the WFH policy. From the provision contained in Article 4 paragraph (2) Government Regulation Number 21 of 2020, people who need needs such as education, work or worship in public places/ facilities can still carry out those activities. From the provisions contained in Article 4 paragraph (3), people who need to fulfill basic needs of the population can still carry out activities in public places/ facilities.

In other words, the implementation of large-scale social restrictions in the context of realizing social distancing/ physical distancing means that the people are encouraged by the government to carry out all daily activities at home. However, people are still permitted to go to public places / facilities on condition that they pay attention to their own safety and to the general public. In social distancing/ physical distancing, there are no restrictions/ prohibitions on someone entering a region/ country even though the region/ country has been affected by COVID-19. Aside from Indonesia, other ASEAN members are also active in appealing to their community in carrying out their daily activities, which will require them to conduct social distancing/ physical distancing.

The last effort taken by ASEAN members are the implementation of lockdown. Lockdown is an effort to handle/ emergency protocol determined by the government of a country where in the effort/ protocol an area/ country access is closed from within and from outside the region/ country. Lockdown has similarities with large-scale social restrictions, but the difference from lockdown and

9 Government Regulation Number 21 of 2020.

10 Government Regulation Number 21 of 2020.

11 Government Regulation Number 21 of 2020.

12 Government Regulation Number 21 of 2020. 
large-scale social restrictions is all public places / facilities that do not sell people's basic needs must be closed for a while. People from countries/ regions that have implemented a lockdown are only allowed to leave if they want to buy basic needs. In addition, all citizens who are in an area/ country that applies a lockdown are prohibited from leaving the region/ country. Some ASEAN members who have implemented lockdown regulations are Singapore, Malaysia, Thailand, the Philippines, Brunei Darussalam and Vietnam. For example, Singapore implemented a lockdown on the grounds that the ineffectiveness of the implementation of national strategies in overcoming COVID-19.

Prime Minister of Singapore, Lee Hsien Loong in a national speech held on April 3, 2020 stated that Singapore's decision to implement a lockdown is like a circuit breaker in cutting off an overload. Lee Hsien Loong argued that the only way to overcome COVID-19 is to apply a lockdown, where if the lockdown is successfully applied the number of COVID-19 cases will gradually decrease. Lee Hsien Long added that to support the sustainability of the lockdown, various government policies were formed, consisting of all workplaces would be closed (except for restaurants, markets, supermarkets, pharmacies, hospitals, public vehicles and banks), all schools and higher education use a full home-based learning system or learning that are carried out entirely at home, and tightens the prohibition and supervision of the movements and associations of people. ${ }^{13}$

The enactment of the lockdown policy is only temporary, not everlasting. So, countries that apply lockdown can revoke lockdown regulations if the subjective assessment of the country considers that the situation is more conducive than before. Until now, the Indonesian government has not implemented a lockdown, considering that the Indonesian government has just implemented large-scale social restrictions. However, it did not rule out the possibility that the Indonesian government could issue a lockdown policy. If the Indonesian government finally decides to implement lockdown (also known as health quarantine in Indonesian positive law), then the legal basis used by the Indonesian government is The Act Number 6 of 2018 concerning on Health Quarantine.

A number of handling efforts have been made in relation to state security by ASEAN members to prevent the spread of COVID-19. However, the handling effort is still insufficient due to the community's very large fear of the spread of COVID-19, so there is still a bad stigma in the community towards victims of COVID-19 which makes the country increasingly insecure. Then, COVID-19 is an outbreak that does not only occur in one country, but several countries both regionally and universally. So, the authors perceive that the ASEAN Political-Security Community, which has a special role in upholding peace and security in the Southeast Asian region, needs to make an effort in order to overcome COVID19. So, what is handling efforts that can be done according to the ASEAN Political-Security Community on overcoming COVID-19 in the Southeast Asian region?

\subsection{Handling efforts that can be done according to the ASEAN Political-Security Community on overcoming COVID-19 in the Southeast Asian region}

${ }^{13}$ Singapore Government. PM Lee: The COVID-19 Situation in Singapore (3 April). Retrieved from https://www.gov.sg/article/pm-lee-hsien-loong-on-the-covid-19-situation-in-singapore-3-apr, Accessed 5 April 2020.

https://journal.unnes.ac.id/sju/index.php//slr/ 
COVID-19 is an epidemic.This is found in almost all over the world, so the problems related to COVID-19 are global problems considering that WHO has declared COVID-19 as a global pandemic. However, there are several reasons why this outbreak is better solved by regional cooperation (regionalization) than by universal cooperation (globalization). Leroy Bennet believes that the advantages of regionalization over globalization are as follows:

1. "There is a natural tendency toward regionalism based on the homogeneity of interests, traditions, and values within small groups of neighboring states.

2. Political, economic, and social integration are easily attained among a lesser number of states within a limited geographic area than on a global basic.

3. Local threats to the peace are more willingly and promptly dealt with by the governments of that area than by disinterested states at greater distances from the scene of conflict.

4. The world is not ready to establish global authority sufficient to maintain world peace and promote world warfare. Regionalism is the first step in gaining experience and building areas of consensus toward eventual intergovernmental coordination or integration." 14

The opinion expressed by Leroy Bennet does not mean countries that are members of regional organizations cannot cooperate with countries outside of regional organizations. In a meeting held by regional organization, it is not uncommon for the meeting to involve countries outside of regional organization members on the grounds that they need and complement each other. Trygvie Lie argued that "regional organization can never replace a world organization". There is an understanding which states that the existence of regional organizations is only as a complement to universal organizations. ${ }^{15}$ In other words, cooperation with regional scope is the first step before cooperation with universal scope. Where all the results obtained from cooperation in the regional scope can be brought and implemented together through cooperation in a larger scope, which is the universal scope.

APSC is a pillar that was formed with specialty to establish peace and security in the Southeast Asian region. Peace and security that was meant include traditional and/ or non-traditional (traditional) peace and security. APSC in carrying out its activities must be in accordance with the values and norms contained in the ASEAN Way. The ASEAN Way is a method for making decisions in the form of consensus / collective agreement, considering that ASEAN is an intergovernmental organization. The provisions regarding the ASEAN Way principles are regulated in Article 20 paragraph (1) of the ASEAN Charter, which states that "As a basic principle, decision-making in ASEAN shall be based on consultation and consensus." 16 In this system, the coordination system between countries dominates in decision-making. ${ }^{17}$ The concept of the ASEAN Way was born from the habits held

14 Puspita, N.Y. (2019). Hukum Regional: ASEAN dan Uni Eropa. Jakarta: Penerbit Universitas Katolik Indonesia Atma Jaya, p.10.

${ }^{15}$ Puspita, N.Y. (2019). Hukum Regional: ASEAN dan Uni Eropa. Jakarta: Penerbit Universitas Katolik Indonesia Atma Jaya, p.15.

16 ASEAN Charter.

17 Puspita, N.Y. (2019). Hukum Regional: ASEAN dan Uni Eropa. Jakarta: Penerbit Universitas Katolik Indonesia Atma Jaya, p. 44. 
by the ASEAN community in solving problems through deliberation. The ASEAN Way concept contains several ASEAN principles, consisting of:

1. Mutual respect for independence, sovereignty, equality, territorial integrity, and national identity of all nations;

2. The right of every state to lead its national existence free from external interference, subversion, or coercion;

3. Non-intervention in internal affairs;

4. Settlement of differences or disputes in a peaceful manner;

5. Renunciation of the threat or use of force; and

6. Effective regional cooperation. 18

One of the most upheld principles by APSC while carrying out its actions is the principle of non-intervention. Amitav Acharya stated "ASEAN considers a pluralistic security community, where each of its members retains its sovereignty". ${ }^{19}$ From the opinion expressed by Amitav, ASEAN respects each of its members by applying the principle of non-intervention. In addition, Rahmadhona added that there are four requirements that must be obliged by each ASEAN member as a consideration of the non-intervention principle requirements, as follow:

1. "Prohibition to criticize any action of a member state against its citizens;

2. Criticizing actions of fellow ASEAN members who violate the principle of nonintervention;

3. Rejecting forms of support for rebel groups that disrupt the national stability of fellow ASEAN members;

4. Providing political support and assistance to the country that is campaigning, and opposing activities that disturb the stability of the country." 20

However, if the country specifically requests assistance from other countries, that country can make bilateral or multilateral agreements so that other countries can help it. If related to the current situation, no country has stated that they need assistance in efforts to deal with COVID-19. APSC also does not intervene in domestic problems faced by ASEAN members. It shows that APSC in carrying out its activities is based on the principle of non-intervention. However, APSC is obliged to make efforts to address COVID-19 in the Southeast Asian region, considering that all ASEAN members have been affected by COVID-19.

In Annex 1 of the ASEAN Charter, it was stated that APSC oversees several meetings, which consist of ASEAN Foreign Ministers Meeting (hereinafter AFMM), Commission on the Southeast Asia Nuclear Weapon-Free, ASEAN Defense Ministers Meeting (hereinafter ADMM), ASEAN Law Ministers Meeting, ASEAN Ministerial Meeting on Transnational Crime and ASEAN Regional Forum (hereinafter ARF). ${ }^{21}$ All the meetings are overseen by APSC. The Meeting efforts to address Covid-19 in Southeast Asia are AFMM, ADMM, and ARF. The results of all meetings are soft law, which means the results of this meeting are not binding on the members.

${ }^{18}$ Heng, M. S. H. (2015), Advancing Community Building for ASEAN. Springer Science+Business. 32 (2). doi: 10.1007/s12140-015-9238-2, p. 428.

${ }^{19}$ Saragih, H.M. (2017). Kebijakan Pembentukan Komunitas ASEAN 2015: Tantangan dan Harapan dalam Penciptaan Stabilitas Kawasan. Jurnal Administrative Reform. 5 (4). ISSN: 23377542, p. 215.

${ }^{20}$ Rahmanto, T.Y. (2017). Prinsip Non-Intervensi Bagi ASEAN dari Perspektif Hak Asasi Manusia. Jurnal HAM. 8 (2). doi: 10.30641/ham.2017.8.330, p. 150.

${ }^{21}$ ASEAN Charter

https://journal.unnes.ac.id/sju/index.php//slr/ 
AFMM is a meeting between the Foreign Ministers of ASEAN members who discuss the development of ASEAN community development. In addition, AFMM also serves as a meeting that formulates policy lines and coordinates ASEAN activities.22 AFMM is held 3 times a year. In addition, the Special ASEAN Ministers Meeting can be held if needed.

Due to the rapidly growing spread of COVID-19, the Special ASEAN Ministers Meeting was held. The Special ASEAN Ministers Meeting was held on February 20, 2020 in Vientiane, Laos under the name Special ASEAN-China Foreign Ministers' Meeting on the Coronavirus Disease 2019 (COVID-19). Special ASEAN Ministers Meeting was attended by all foreign ministers of ASEAN members and the foreign minister of China. The holding of the Special ASEAN-China Foreign Ministers' Meeting on the Coronavirus Disease 2019 (COVID-19) was caused by the desire of all countries participating in this meeting to collaborate to prevent the spread and overcome COVID-19. In the Special ASEAN-China Foreign Ministers' Meeting on the Coronavirus Disease 2019 (COVID-19), several things were agreed:

1. "Step up cooperation in the region against COVID-19 by sharing information and best practices in a timely manner;

2. Strengthen cooperation within ASEAN-led mechanisms and with external partners to address COVID-19 in a comprehensive and effective manner;

3. Strengthen cooperation in risk communication and community engagement readiness and response to ensure that people are rightly and thoroughly informed on COVID-19 and are not being misled by misinformation and fake news pertaining to COVID-19;

4. Strengthen policy dialogue and exchanges on the latest development of the COVID-19, including its control and treatment, and its related study and research

5. Work together to enhance the capacity to prevent and control emerging and reemerging infectious and communicable diseases such as COVID-19;

6. Mitigate supply chain disruptions of urgent medical goods and promote research and development of medicines and vaccines;

7. Support enterprises affected by the epidemic, especially micro, small and medium-sized enterprises (MSMEs), as appropriate;

8. Support the use of information and communication technologies for the continued development of public health;

9. Commit to reduce the impact of the epidemic on the economic and social development of all affected countries, jointly maintaining people-to-people exchanges, trade and investment activities in the region, and, based on the progress of the prevention and control of the epidemic, resume and enhance exchanges and cooperation." 23

ADMM is a forum for cooperation between the Ministers of Defense of ASEAN members that aims to improve Confidence Building Measures, maintain

22 Sekretariat Nasional ASEAN - Indonesia. ASEAN Foreign Ministerial Meeting (AMM). Retrieved from http://setnas-asean.id/asean-foreign-ministers-meeting-amm, Accessed on 6 April 2020.

${ }^{23}$ Special ASEAN-China Foreign Ministers' Meeting on the Coronavirus Disease 2019 (COVID19).

https://journal.unnes.ac.id/sju/index.php/IsIr/ 
peace and stability in the region. The purpose of the ADMM is to discuss and exchange views and opinions on defense and security issues faced by ASEAN. ${ }^{24}$

In 2020, the ASEAN Defense Ministers Meeting was held on 19 February 2020 in Hanoi, Vietnam. The topic of the ASEAN Defense Ministers Meeting 2020 is "Regional and International Security Issues of Common Interest". The ASEAN Defense Ministers Meeting 2020 was attended by all defense ministers/ representatives from 10 ASEAN members. One of the topic discussions in the ASEAN Defense Ministers Meeting was about handling COVID-19. In the ASEAN Defense Ministers Meeting 2020, several things were agreed:

1. "Enhance practical cooperation among ASEAN defence establishments to organize information and best practice sharing activities, and with our external partners, bilaterally or multilaterally;

2. Utilize the Network of ASEAN Chemical, Biological and Radiological Defence Experts to enhance professional linkages, and promote scientific cooperation to manage infectious disease outbreaks;

3. Encourage new initiatives and ways of cooperation contributing to ASEAN's overall efforts to counter fake news regarding the COVID-19 outbreak and ensure our people are well informed of the situation;

4. Cooperate proactively with other relevant sectoral bodies of ASEAN in tackling the COVID-19 in the spirit of ASEAN's solidarity, and with other countries in the region and the world;

5. Do our part for public health and social cohesion by supporting the efforts of our respective national health authorities as well as utilizing ASEAN's regional health mechanisms for coordination and cooperation in response to this emerging public health threat;

6. Remain resolutely committed to doing our part, and staying united to overcome the COVID-19 outbreak for the benefit of the people of ASEAN." 25

Besides AFMM and ADMM, another meeting overseen by the ASEAN Political-Security Community is the ASEAN Regional Forum (hereinafter ARF). ARF is a meeting that acts as a means for dialogue and consultation on matters relating to politics and security in the Asia Pacific region. ARF consists of countries that are members of ASEAN and countries that are not members of ASEAN. ${ }^{26}$

Currently, ARF meeting on handling COVID-19 has not been held. The ARF is planned to be held on March 14, 2020 in Las Vegas, United States, but it was postpone due to the spread of Covid-19. Although the ARF results are soft law, but the results of the problem solving process by ARF members are expected to be implemented as an effort to prevent the spread of covid-19.

ASEAN members must find an accurate way through the APSC pillar in order to deal with COVID-19, which is currently underway. Manifestation in this matter can be realized with the awareness of every ASEAN member of the dangers that are already clearly visible. In Article 2 paragraph (2) point b of the ASEAN Charter, it is

24 Sekretariat Nasional ASEAN - Indonesia. ASEAN Defence Ministerial Meeting (AMM). Retrieved from http://setnas-asean.id/asean-defence-ministers-meeting-admm, Accessed on 6 April 2020.

${ }^{25}$ Joint Statement by the ASEAN Defence Ministers on Defence Cooperation Against Disease Outbreaks.

${ }^{26}$ Puspita, N.Y. (2019). Hukum Regional: ASEAN dan Uni Eropa. Jakarta: Penerbit Universitas Katolik Indonesia Atma Jaya, p. 59.

\section{https://journal.unnes.ac.id/sju/index.php/Islr/}


stated that "shared commitment and collective responsibility in enhancing regional peace, security and prosperity." 27 This principle means that all security-related phenomena occurring in the Southeast Asian region must be addressed together. One of the means referred to be the establishment of a legal enactment by APSC related to efforts to deal with COVID-19.

COVID-19 is an outbreak faced by ASEAN members collectively and simultaneously, so that with the formulation of legal enactment through various meetings by APSC it is hoped that COVID-19 will be addressed as soon as possible. The members who participate in making the legal enactment must have good faith in carrying out the provisions stipulated in the legal enactment. Regarding good faith, there are no specific limitations because good faith is subjective. Since all ASEAN members have been affected by COVID-19, all countries participating in meetings held and overseen by the APSC will think to better implement the contents of the meeting. This is due to the meeting being attended by fellow countries that have been affected by COVID-19 and they want to put forward the principle of shared responsibility so that they can jointly overcome COVID-19 in the Southeast Asia region and universally. The principle of joint responsibility can be interpreted as a principle whereby the entire state, community, international organizations and other actors involved in. It work together and support each other concerning to all efforts to overcome the problems that have been taken. ${ }^{28}$ If a country does not carry out the contents of the meeting, of course it will cause its own loss for the country.

The provisions made by APSC cannot bind the members, because the soft law provisions are only morally binding and not legally binding. No provisions related to sanctions that can be given to parties who think otherwise which ultimately causes them to not carry out their obligations as stipulated in the legal enactment made by APSC .However, if the provisions made by APSC are carried out in good faith and the principle of shared responsibility is upheld and implemented on an ongoing basis by ASEAN members, then efforts to deal with COVID-19 can be realized.

\section{Conclusion}

Coronavirus Disease 2019 (COVID-19) is a global pandemic, because it can easily infect one person to another in many countries at the same time, and for which there is no vaccine yet. The impact caused by COVID-19 is very detrimental to countries and communities throughout the world in various aspects of life. All ASEAN members have been affected by COVID-19. ASEAN members have made various handling efforts related to aspects of national security, by issuing policies such as: travel ban, social distancing/ physical distancing, and lockdown. However, the APSC which was formed with the aim of upholding peace and security in the Southeast Asian region has an obligation to make efforts to deal with ASEAN members who have been affected by the COVID-19 outbreak. Various efforts have been made by the APSC with the

\footnotetext{
27 ASEAN Charter.

28 Aryanti, J.E. \& Leksono, H. (2017). Penerapan Prinsip Shared Responsibility Sebagai Upaya dalam Penanggulangan Kejahatan Transnasional di Kawasan Asia Tenggara. Belli ac Pacis, 3(2). ISSN 2460-5247, p. 27.
} 
implementation of the Special ASEAN-China Foreign Ministers' Meeting on the Coronavirus Disease 2019 (COVID-19) and the ASEAN Defense Ministers Meeting 2020. Members are required to have good faith and prioritize the principle of shared responsibility in carrying out the contents of the meeting. So that the COVID-19 prevention and control efforts in the Southeast Asia and the universal region can be realized considering that the contents of the two meetings are soft law. The ASEAN Regional Forum must also be held as soon as possible in the hope that the outcome of the meeting can be implemented into a policy made by the country which has already affected by COVID-19 as an effort to prevent the spread and overcome COVID-19.

\section{Acknowledgments}

With the completion of writing the paper entitled "Handling COVID-19 Related to Regional Security According to ASEAN Political-Security Community", the author would like to express his deepest gratitude to:

a. The Almighty God, because of his blessings, the author can finish writing this paper.

b. Mr. Fachrudin Sembiring, S.H., M.H., as a lecturer of Regional Law who has provided direction and advice to the author so that the author can finish writing this paper.

c. My family and friends from Atma Jaya Catholic University of Indonesia who have supported and motivated the author from the beginning until the writer can finish writing this paper.

\section{References}

Books :

Fuady, M. (2018). Metode Riset Hukum: Pendekatan Teori dan Konsep. Depok: Rajawali Pers

Puspita, N.Y. (2019). Hukum Regional: ASEAN dan Uni Eropa. Jakarta: Penerbit Universitas Katolik Indonesia Atma Jaya.

\section{Journals :}

Aryanti, J.E. \& Leksono, H. (2017). Penerapan Prinsip Shared Responsibility Sebagai Upaya dalam Penanggulangan Kejahatan Transnasional di Kawasan Asia Tenggara, Belli ac Pacis, 3(2), 27-36. ISSN 2460-5247.

Heng, M. S. H. (2015). Advancing Community Building for ASEAN, Springer Science+Business. 32 (2). doi: 10.1007/s12140-015-9238-2.

Jun, Y.C. (2016). Essence of Security Communities: Explaining ASEAN, International Relations of the Asia-Pacific. 16 (3). 335-369. doi: 10.1093/irap/lcv026.

Rahmanto, T.Y. (2017). Prinsip Non-Intervensi Bagi ASEAN dari Perspektif Hak Asasi Manusia, Jurnal HAM. 8 (2). 145-159. doi: 10.30641/ham.2017. 8.330.

Saragih, H.M. (2017). Kebijakan Pembentukan Komunitas ASEAN 2015: Tantangan dan Harapan dalam Penciptaan Stabilitas Kawasan, Jurnal Administrative Reform. 5 (4). 213-226. ISSN: 2337-7542.

Siallagan, H. (2016). Penerapan Prinsip Negara Hukum di Indonesia, Sosiohumaniora. 18 (2). 131-137. doi: 10.24198/sosiohumaniora.v18i2.9947.

\section{Online/World Wide Web :}

\section{https://journal.unnes.ac.id/sju/index.php/Islr/}


John Hopkins University. (2020). Coronavirus COVID-19 Global Cases by the Center of Systems Science and Engineering (CSSE). Retrieved from https://www.arcgis.com/apps/opsdashboard/index.html\#/bda7594740fd40 299423467b48e9ecf6, Accessed on April 262020.

Sekretariat Nasional ASEAN - Indonesia. ASEAN Defence Ministerial Meeting (AMM). Retrieved from http://setnas-asean.id/asean-defence-ministersmeeting-admm, Accessed on April 62020.

Sekretariat Nasional ASEAN - Indonesia. ASEAN Foreign Ministerial Meeting $(A M M)$._Retrieved from http://setnas-asean.id/asean-foreign-ministersmeeting-amm, Accessed on April 62020.

Singapore Government. (2020). PM Lee: The COVID-19 Situation in Singapore (3 April). Retrieved from https://www.gov.sg/article/pm-lee-hsien-loong-onthe-covid-19-situation-in-singapore-3-apr, Accessed on April 52020.

World Health Organization. (2020). Physical Distancing. Retrieved from https://www.who.int/docs/default-source/coronaviruse/transcripts/whoaudio-emergencies-coronavirus-press-conference-full20mar2020.pdf?sfvrsn=1eafbff_0 , Accessed on April 262020.

\section{Laws and Regulations:}

2008. The ASEAN Charter. 25 November 2007. ASEAN Secretariat. Singapore.

2009. ASEAN Political-Security Community Blueprint. ASEAN Secretariat. Jakarta.

2020. Joint Statement by the ASEAN Defence Ministers on Defence Cooperation Against Disease Outbreaks. 19 February 2020. ASEAN Secretariat. Hanoi.

2020. Special ASEAN-China Foreign Ministers' Meeting on the Coronavirus Disease 2019 (COVID-19). 20 February 2020. ASEAN Secretariat. Vientiane.

The Ministerial Regulation of Law and Human Right Number 11 of 2020 concerning Temporary Prohibition of Foreigners from Entering the Territory of the Republic of Indonesia. March 31, 2020. Jakarta.

The Government Regulation of Republic Indonesia Number 21 of 2020 concerning Large-Scale Social Restrictions in the Context of Accelerating Handling of Coronavirus Disease 2019 (COVID-19). March 31, 2020. State Gazette of the Republic of Indonesia Year 2020 Number 91. Jakarta. 


\section{LEGAL ADAGE}

\section{ALTERUM NON LAEDERE}

\section{Your Action Should not Harm Others}

